\title{
HUBUNGAN ANTARA KECERDASAN EMOSIONAL DENGAN KONFORMITAS SISWA KELAS VIII SMP N 1 KANDANGAN, KABUPATEN TEMANGGUNG TAHUN AJARAN 2018/2019
}

\author{
Desi Kuswijayanti ${ }^{1}$ Umbu Tagela $^{2}$ Setyorini $^{3}$ \\ Email: 132015058.student.uksw.edu umbu.tagela@staff.uksw.edu ${ }^{2}$ \\ rinny_bk@yahoo.com ${ }^{3}$ \\ Progam Studi Bimbingan dan Konseling Fakultas Keguruan dan Ilmu Pendidikan \\ Universitas Kristen Satya Wacana ${ }^{1,2,3}$
}

\begin{abstract}
Abstrak
Penelitian ini adalah penelitian korelasional yang bertujuan untuk menguji hubungan antara tingkat kecerdasan emosional dengan konformitas. Hipotesis yang diajukan dalam penelitian ini adalah ada hubungan negatif yang signifikan antara tingkat kecerdasan emosional dengan konformitas. Populasi dalam penelitian ini sebanyak 246 orang siswa kelas VIII SMP Kandangan Kab. Temanggung dan sampel yang digunakan dalam penelitian ini sebanyak 146 orang siswa kelas VIII SMP Kandangan Kab. Temanggung. Teknik pengambilan sampel menggunakan teknik Isaac dan Michael. Pengumpulan data menggunakan dua jenis skala, yaitu skala kecerdasan emosional dan skala konformitas, yang dikembangkan oleh peneliti berdasarkan teori Salovey dan Mayer dan teori Sears (1999). Teknik analisis data yang digunakan dalam penelitian ini menggunakan korelasi kendall's tau- $b$, dan pengolahan datanya menggunakan progam SPSS for Windows 20.0 version. Hasil penelitian menunjukkan bahwa ada hubungan negatif yang signifikan antara tingkat kecerdasan emosional dengan konformitas pada siswa kelas VIII SMP Kandangan Kab. Temanggung ditunjukkan nilai $r=-0,682$ dengan taraf signifikan $0,000 \leq 0,05$. Artinya semakin tinggi konformitas maka tingkat kecerdasan emosional semakin rendah.
\end{abstract}

Kata Kunci : Kecerdasan Emosional; Konformitas

\begin{abstract}
This study is a correlational study that aims to examine the relationship between the level of emotional intelligence and conformity. The hypothesis proposed in this study is that there is a significant negative relationship between the level of emotional intelligence and conformity. The population in this study were 246 students of class VIII Middle School Kandangan Kab. Temanggung and the sample used in this study were 146 students of class VIII Middle School Kandangan Kab. Temanggung. The sampling technique uses the techniques of Isaac and Michael. Data collection uses two types of scales, namely the emotional intelligence scale and conformity scale, which was developed by researchers based on Salovey and Mayer's theory and Sears (1999) theory. The data analysis technique used in this study uses Kendall's tau-b correlation, and the data processing uses the SPSS program for Windows 20.0 version. The results showed that there was a significant negative relationship between the level of emotional intelligence and conformity in class VIII Kandangan Kab. Temanggung shows the value of $r=-0.682$ with a significant level of 0,000 5 0.05. This means that the higher the conformity, the lower the level of emotional intelligence.
\end{abstract}

Keywords: Emotional Intelligence; Conformity

\section{PENDAHULUAN}

Manusia pada dasarnya adalah tercipta sebagai makhluk individual sekaligus makhluk sosial. Manusia sebagai makhluk sosial yang saling membutuhkan, saling memberikan pengaruh dan memiliki keinginan untuk saling berkumpul dan saling berinteraksi satu dengan yang lainnya. Dalam proses sosialisasi, remaja biasanya akan mendapatkan pengaruh sosial lebih banyak dari teman-teman sekolahnya atau teman sebayanya dibandingkan dengan keluarga dan masyarakat. Hal ini dikarenakan remaja lebih banyak menghabiskan waktunya di sekolah 
bersama dengan teman-temannya dengan lamanya jam sekolah yang memakan waktu kurang lebih selama delapan jam, belum lagi jika siswa mengikuti ekstrakulikuler di sekolah maka akan semakin lama ia berada di sekolah dan waktu untuk bersosialisasi banyak digunakan remaja pada teman sekolahnya dan teman sebayanya. Setiap orang pasti memiliki keempatnya karena menggambarkan keutuhan diri atau hakikat diri.

Manusia mencoba menyesuaikan diri dengan lingkungan agar dapat bertahan hidup. Cara yang termudah adalah melakukan tindakan yang sesuai dan diterima secara sosial. Sarlito W. Sarwono \& Eko A. Meinarno, (2009) mengatakan "melakukan tindakan yang sesuai dengan norma sosial dalam psikologi sosial dikenal sebagai konformitas".

Selanjutnya Baron, Branscombe, Byrne, (Sarlito W. Sarwono \& Eko A. Meinarno, 2009) mendefinisikan konformitas adalah "suatu bentuk pengaruh sosial dimana individu mengubah sikap dan tingkah lakunya agar sesuai dengan norma sosial”. Konformitas dapat berperan secara positif atau negatif pada seorang remaja, peran negatif biasanya berupa penggunaan bahasa yang hanya dimengerti oleh para anggota kelompoknya saja dan keluar dari norma yang baik.

Menurut Semuel S. Lusi, (2014)“Tanpa salah satunya, seseorang tidak dapat menjadi pribadi yang utuh dan terintegrasi”. Kecerdasan dasar manusia melibatkan aspek kehidupan mulai dari menentukan sikap sehari-hari, membuat keputusan, melakukan hal-hal praktis, sampai berinovasi, berkreasi, meyelesaikan masalah, menghadapi krisis dan tantangan.

$$
\text { Kepekaan dalam mengelola }
$$
perasaan ini kemudian menjadi kerangka dalam berperilaku, bersosial atau mengambil keputusan yang tepat. Berkaitan dengan hubungan sosial, remaja harus menyesuaikan diri dengan orang di luar lingkungan keluarga, seperti kelompok teman sebaya. Pengaruh kelompok sebaya terjadi karena remaja lebih banyak berada di luar rumah bersama dengan teman sebaya sebagai kelompok. Kelompok teman sebaya memiliki aturan tertentu yang harus dipatuhi oleh remaja sebagai anggota kelompoknya. Monks (Haditono, 2002) menyatakan "penyesuaian remaja terhadap norma dengan berperilaku sama dengan kelompok teman sebaya disebut konformitas".

Kecerdasan dalam mengemukakan emosional merupakan suatu proses 
kemampuan individu menempatkan segala perasaannya dengan tepat dan benar. Menurut Semuel S. Lusi, (2014) "Seseorang akan kehilangan kemanusiaannya bila tidak memiliki emosional dan hati". Tanpa unsur emosional, manusia kehilangan daya, koneksi dan empati. Salah satu aspek kecerdasan emosional yaitu kecerdasan sosial, kemampuan untuk memahami orang lain dan bertindak bijaksana dalam hubungan antar manusia.

Masa remaja banyak menghabiskan waktunya di sekolah, sehingga apabila aktivitas yang dijalaninya di sekolah tidak memadai untuk memenuhi tuntutan gejolak energinya, maka remaja seringkali meluapkan kelebihan energinya ke arah yang negatif. Hal ini menunjukkan betapa besar gejolak emosional yang ada dalam diri remaja bila berinteraksi dengan lingkungannya.

Tingkat rendahnya kecerdasan emosional juga bisa berpengaruh terhadap perilaku konformitas, hal ini disebabkan karena rendahnya tingkat kecerdasan emosional menjadikan tidak mampu mengendalikan dorongan emosional dan tidak mampu menghargai atau berempati terhadap orang lain.

Menurut Daniel Goleman, (2002) kecerdasan emosional "bukanlah keterampilan yang saling bertentangan, melainkan keterampilan yang sedikit terpisah yang mencampurkan ketajaman akal dan ketajaman emosional”. Orang dengan IQ tinggi tetapi kecerdasan emosional rendah (atau IQ rendah dengan kecerdasan emosional tinggi). Sehubungan dengan hal tersebut Dani Ronnie M, (2006) mengatakan kecerdasan emosional adalah "kepekaan mengenali dan mengelola perasaan sendiri (self awareness) dan orang lain (empathy)".

Berdasarkan wawancara dengan a guru pembimbing di SMP Negeri 1 Kandangan Kab.Temanggung diperoleh informasi bahwa sebagian siswa kelas VIII SMP Negeri 1 Kandangan mempunyai perilaku konformitas yang tinggi seperti melakukan kenakalan, mecontek, meminum minuman keras, merokok dan bermasalah dengan orang tua dan guru kemungkinan disebabkan oleh kecerdasan emosionalnya yang rendah seperti sulit bergaul, tempramen, agresif dan kurang ekspresif.

Berdasarkan uraian di atas, penulis tertarik melakukan penelitian tentang Hubungan Antara Kecerdasan Emosional dengan Konformitas Siswa Kelas VIII SMP Negeri 1 Kandangan Kab.Temanggung Tahun Ajaran 2018/2019. 


\section{KAJIAN PUSTAKA}

\section{Hubungan Antara Kecerdasan Emosional dan Konformitas}

Manusia pada dasarnya adalah tercipta sebagai makhluk individual sealigus makhluk sosial. Manusia sebgai makhluk sosial yang saling membutuhkan, saling memberikan pengaruh dan memiliki keinginan untuk saling berkumpul dan saling berinteraksi satu dengan yang lainnya.

Dalam proses sosialisasi, remaja biasanya akan mendapatkan pengaruh sosial lebih banyak dari teman-teman sekolahnya atau teman sebayanya dibandingkan dengan keluarga dan masyarakat. Hal ini dikarenakan remaja lebih banyak menghabiskan waktunya di sekolah bersama dengan teman-temannya dengan lamanya jam sekolah yang memakan waktu kurang lebih selama delapan jam, belum lagi jika siswa mengikuti ekstrakulikuler di sekolah maka akan semakin lama ia berada di sekolah dan waktu untuk bersosialisasi banyak digunakan remaja pada teman sekolahnya dan teman sebayanya. Setiap orang pasti memiliki keempatnya karena menggambarkan keutuhan diri atau hakikat diri.

Manusia mencoba menyesuaikan diri dengan lingkungan agar dapat bertahan hidup. Cara yang termudah adalah melakukan tindakan yang sesuai dan diterima secara sosial. Sarlito W. Sarwono \& Eko A. Meinarno, (2009) mengatakan "melakukan tindakan yang sesuai dengan norma sosial dalam psikologi sosial dikenal sebagai konformitas".

Selanjutnya Baron, Branscombe, Byrne, (Sarlito W. Sarwono \& Eko A. Meinarno, 2009) mendefinisikan konformitas adalah "suatu bentuk pengaruh sosial dimana individu mengubah sikap dan tingkah lakunya agar sesuai dengan norma sosial". Konformitas dapat berperan secara positif atau negatif pada seorang remaja, peran negatif biasanya berupa penggunaan bahasa yang hanya dimengerti oleh para anggota kelompoknya saja dan keluar dari norma yang baik.

Menurut Semuel S. Lusi, (2014)"tanpa salah satunya, seseorang tidak dapat menjadi pribadi yang utuh dan terintegrasi". Kecerdasan dasar manusia melibatkan aspek kehidupan mulai dari menentukan sikap sehari-hari, membuat keputusan, melakukan hal-hal praktis, sampai berinovasi, berkreasi, meyelesaikan masalah, menghadapi krisis dan tantangan.

Kepekaan dalam mengelola perasaan ini kemudian menjadi kerangka dalam berperilaku, bersosial atau 
mengambil keputusan yang tepat. Berkaitan dengan hubungan sosial, remaja harus menyesuaikan diri dengan orang di luar lingkungan keluarga, seperti kelompok teman sebaya. Pengaruh kelompok sebaya terjadi karena remaja lebih banyak berada di luar rumah bersama dengan teman sebaya sebagai kelompok. Kelompok teman sebaya memiliki aturan tertentu yang harus dipatuhi oleh remaja sebagai anggota kelompoknya. Monks (Haditono, 2002) menyatakan "penyesuaian remaja terhadap norma dengan berperilaku sama dengan kelompok teman sebaya disebut konformitas".

Kecerdasan dalam mengemukakan emosional merupakan suatu proses kemampuan individu menempatkan segala perasaannya dengan tepat dan benar. Menurut Semuel S. Lusi, (2014) "Seseorang akan kehilangan kemanusiaannya bila tidak memiliki emosional dan hati". Tanpa unsur emosional, manusia kehilangan daya, koneksi dan empati. Salah satu aspek kecerdasan emosional yaitu kecerdasan sosial, kemampuan untuk memahami orang lain dan bertindak bijaksana dalam hubungan antar manusia.

Masa remaja banyak menghabiskan waktunya di sekolah, sehingga apabila aktivitas yang dijalaninya di sekolah tidak memadai untuk memenuhi tuntutan gejolak energinya, maka remaja seringkali meluapkan kelebihan energinya ke arah yang negatif. Hal ini menunjukkan betapa besar gejolak emosional yang ada dalam diri remaja bila berinteraksi dengan lingkungannya.

Tingkat Rendahnya kecerdasan emosional juga bisa berpengaruh terhadap perilaku konformitas, hal ini disebabkan karena rendahnya tingkat kecerdasan emosional menjadikan tidak mampu mengendalikan dorongan emosional dan tidak mampu menghargai atau berempati terhadap orang lain.

Hal ini menunjukkan betapa besar gejolak emosional yang ada dalam diri remaja bila berinteraksi dengan lingkungannya. Rendahnya kecerdasan emosional juga bisa berpengaruh terhadap perilaku konformitas, hal ini disebabkan karena rendahnya tingkat kecerdasan emosional menjadikan tidak mampu mengendalikan dorongan emosional dan tidak mampu menghargai atau berempati terhadap orang lain.

Berdasarkan uraian diatas, maka hipotesis dalam penelitian ini dirumuskan sebagai berikut: Ada hubungan negatif yang signifikan antara tingkat kecerdasan emosional dengan konformitas pada siswa kelas VIII SMP Negeri 1 Kandangan Kab.Temanggung. 


\section{METODE PENELITIAN}

Jenis penelitian yang digunakan oleh peneliti adalah penelitian korelasional. Menurut Arikunto (2006), penelitian korelasi bertujuan untuk menemukan ada tidaknya hubungan dan apabila ada, seberapa eratnya hubungan tersebut. Berarti dalam penelitian ini dicari adanya hubungan antara Tingkat Kecerdasan Emosional Dan Konformitas Pada Siswa Kelas VIII SMP N 1 Kandangan Temanggung. Dengan teknik korelasional peneliti dapat mengetahui hubungan variasi dalam sebuah bentuk variabel lain. Besar atau tingginya hubungan tersebut dinyatakan dalam bentuk koefisien korelasi.

Variabel penelitian ini adalah kecerdasan emosional sebagai variabel $\mathrm{X}$ dan konformitas sebagai variabel $\mathrm{Y}$. Variabel merupakan suatu atribut atau sifat atau nilai dari orang, obyek, atau kegiatan yang mempunyai variasi tertentu yang ditetapkan oleh peneliti untuk dipelajari dan ditarik kesimpulannya (Sugiyono, 2015).

Populasi dari penelitian ini adalah siswa-siswa kelas VIII SMP $\mathrm{N} \quad 1$ Kandangan Temanggung yang berjumlah 246 siswa yang terbagi dalam 8 kelas. Sedangkan sampel Sampel yang akan digunakan dalam penelitian ini adalah strata random sampling. Strata Random sampling adalah teknik pengambilan sampel yang dilakukan dengan cara mencampur subjek-subjek yang ada didalam populasi sehingga semua subjek dianggap sama (Suharsimi Arikunto, 2006).

Cara pengambilan sampel menggunakan teknik Isaac dan Michael. Dalam penentuan jumlah sampel, ditentukan dengan menentukan jumlah kesalahan pada populasai antara $1 \%, 5 \%$, dan 10\% pada tabel (Sugiyono, 2010). Selanjutnya untuk mendapatkan jumlah sampel per strata dihitung dengan menggunakan rumus jumlah populasi strata/jumlah populasi $\mathrm{x}$ jumlah sampel yang tertera pada tabel. Dalam penelitian ini, peneliti menggunakan tingkat kesalahan 5\% sehingga berdasarkan tabel (Sugiyono, 2010), dari populasi sebanyak 246 siswa didapat sampel sebanyak 146 siswa.

Metode pengumpulan data adalah cara yang digunakan peneliti dalam mengumpulkan data. Azwar (2009) menjelaskan bahwa metode pengumpulan data dalam kegiatan penelitian mempunyai tujuan untuk mengungkap fakta mengenai variabel yang diteliti. Data dalam penelitian ini diperoleh dari alat pengumpulan data berupa skala sikap. Skala sikap yang akan digunakan 
dalam penelitian ini meliputi skala kecerdasan emosi dan skala konformitas.

Dalam penelitian ini uji coba validitas instrumen dilakukan pada siswa kelas VIII B, uji coba instrumen dilakukan satu kali sekaligus dua inventori kepada 30 peserta didik.

Berdasarkan hasil uji validitas item variabel kecerdasan emosional terdapat 30 item (keseluruhan) tergolong valid dengan rentang koefisien korelasi 0,392 0,822 . Sedangkan hasil uji validitas item variabel konformitas terdapat 30 item (keseluruhan) tergolong valid dengan rentang korelasi 0,405 - 0,823. Dengan demikian maka item variabel kecerdasan emosional dan item variabel konformitas dinyatakan valid karena koefisien korelasi $\geq 0,20$.

Uji reliabilitas dilihat pada nilai Alpha-Croncbach untuk reliabilitas keseluruhan item dalam satu variabel. Pada variabel kecerdasan emosional diperoleh hasil $\alpha=0,964$ dan pada variabel konformitas diperoleh hasil $\alpha=$ 0,963 sehingga instrumen dalam penelitian ini dapat dikatakan memiliki reliabilitas pada kategori sangat bagus.

Dalam penelitian ini pengolahan data dianalisis dengan menggunakan progam SPSS For Windows versi 21. Teknik analisis data menggunakan teknik korelasi kendall's tau-b, teknik ini digunakan untuk menampilkan hasil hubungan antara dua variabel yaitu variabel kecerdasan emosioanl dan variabel konformitas. Teknik korelasi kendall's tau-b ini digunakan untuk menganalisa signifikansi hubungan antara dua variabel diatas.

\section{HASIL PENELITIAN DAN PEMBAHASAN}

Penelitian ini dilaksanakan pada bulan November 2018 - Februari 2019. Data yang diperoleh dalam penelitian ini merupakan hasil analisis dari skala kecerdasan emosional dan skala konformitas. Skala ini digunakan untuk mengetahui tingkat kecersdasan emosional dan tingkat konformitas yang dimiliki oleh siswakelas VIII di SMP N 1 Kandangan Temanggung.

Peneliti mengkategorikan subyek penelitian menjadi lima, yaitu sangat tinggi, tinggi, sedang, rendah, dan sangat rendah.

\section{Analisis Deskripsi Kecerdasan Emosional}

Kecerdasan emosional pada peserta didik diukur dengan menggunakan skala kecerdasan emosional dengan menggunakan empat pilihan jawaban. Skala ini memiliki jumlah pernyataan sebanyak 30 butir dengan skor jawaban tertinggi 4 dan skor jawaban terendah 1 . Untuk mengetahui tingkat kecerdasan 
emosional peserta didik dalam kategori sangat tinggi, tinggi, sedang, rendah, dan sangat rendah maka dapat dihitung menggunakan rumus sebagai berikut :

Tabel 1. Distribusi Frekuensi Kecerdasan Emosional

\begin{tabular}{|l|l|l|l|}
\hline Kategori & Interval & Frekuensi & $\begin{array}{l}\text { Presentase } \\
(\%)\end{array}$ \\
\hline $\begin{array}{l}\text { Sangat } \\
\text { tinggi }\end{array}$ & $\geq 100$ & 20 & $13,7 \%$ \\
\hline Tinggi & $87-99$ & 43 & $29,5 \%$ \\
\hline Sedang & $74-86$ & 34 & $23,3 \%$ \\
\hline Rendah & $61-73$ & 42 & $28,8 \%$ \\
\hline $\begin{array}{l}\text { Sangat } \\
\text { rendah }\end{array}$ & $48-60$ & 7 & $4,8 \%$ \\
\hline Total & 146 & $100 \%$ \\
\hline Min & 48 & \\
\hline Max & 113 & \\
\hline
\end{tabular}

Berdasarkan tabel 1. dapat diketahui bahwa kecerdasan emosional siswa kelas VIII SMP N 1 Kandangan sebagian besar berada pada kategori rendah dengan presentase $32,1 \%$.

\section{Analisis Deskripsi Konformitas}

Konformitas pada peserta didik diukur dengan menggunakan skala konformitas dengan menggunakan empat pilihan jawaban. Skala ini memiliki jumlah pernyataan sebanyak 30 butir dengan skor jawaban tertinggi 4 dan skor jawaban terendah 1 . Untuk mengetahui tingkat konformitas peserta di dalam kategori sangat tinggi, tinggi, sedang, rendah, dan sangat rendah maka dapat dihitung menggunakan rumus sebagai berikut :
Tabel 2. Distribusi Frekuensi Kematangan Karir

\begin{tabular}{|l|l|l|l|}
\hline Kategori & Interval & Frekuensi & $\begin{array}{l}\text { Presentase } \\
(\%)\end{array}$ \\
\hline $\begin{array}{l}\text { Sangat } \\
\text { tinggi }\end{array}$ & $\geq 100$ & 37 & $25,3 \%$ \\
\hline Tinggi & $87-99$ & 44 & $30,1 \%$ \\
\hline Sedang & $74-86$ & 27 & $18,5 \%$ \\
\hline Rendah & $61-73$ & 29 & $19,9 \%$ \\
\hline $\begin{array}{l}\text { Sangat } \\
\text { rendah }\end{array}$ & $48-60$ & 9 & $6,2 \%$ \\
\hline Total & 146 & $100 \%$ \\
\hline Min & 48 & \\
\hline Max & 113 & \\
\hline
\end{tabular}

Berdasarkan tabel 2. diatas dapat diketahui bahwa konformitas siswa kelas VIII SMP N 1 Kandangan Temanggung sebagian besar berada pada kategori tinggi dengan presentase $30,1 \%$.

\section{Uji Hipotesis}

Uji hipotesis bertujuan untuk mengetahui ada atau tidak ada hubungan (korelasi) antara kecerdasan emosional dengan konformitassiswa kelas VIII SMP N 1 Kandangan Temanggung. Pengujian korelasi menggunakan kendall's tau dengan menggunakan SPSS 21.0 for Windows, hasil uji korelasi dapat dilihat pada tabel 3 sebagai berikut:

\section{Tabel 3. Hasil Uji Hipotesis}

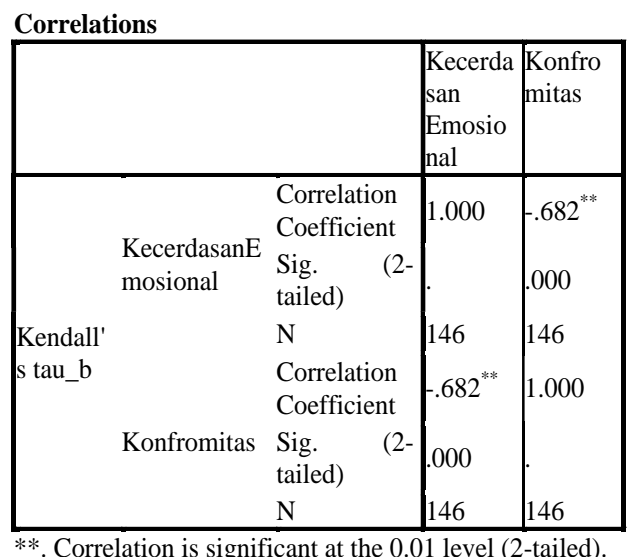


Berdasarkan hasil uji korelasi diatas maka diketahui nilai $r=-0,682$ dengan taraf signifikan $0,000 \leq 0,05$, dengan demikian dapat ditarik kesimpulan bahwa ada hubungan negatif yang signifikan antara antara kecerdasan emosional dengan konformitas siswa kelas VIII SMP N 1 Kandangan Temanggung.

\section{Pembahasan}

Berdasarkan uji hipotesis yang telah dilakukan, menunjukkan hasil bahwa terdapat hubungan negatif dan signifikan antara kecerdasan emosional dengan konformitas. Diketahui koefisien korelasi antara kecerdasan emosional dengan konformitas sebesar $-0,682$ dengan demikian hipotesis alternatif diterima dan berbunyi terdapat hubungan negatif yang signifikan antara kecerdasan emosional dengan konformitas.

Hasil ini mendukung penelitian yang telah dilakukanoleh Fema Rachmawati tahun 2013 yang berjudul Hubungan Antara Kecerdasan Emosi Dengan Konformitas Pada Remaja di SMA Muhammadiyah 3 Yogyakarta dengan hasil $\left(\mathrm{r}_{\mathrm{xy}}\right)$ sebesar $-0,278$ dengan $\mathrm{p}<0,002$.

Hasil penelitian ini juga mendukung pernyataan Semuel S. Lusi, (2014) "Seseorang akan kehilangan kemanusiaannya bila tidak memiliki emosional dan hati”. Rendahnya kecerdasan emosional juga bisa berpengaruh terhadap perilaku konformitas, hal ini disebabkan karena rendahnya tingkat kecerdasan emosional menjadikan seseorang tidak mampu mengendalikan dorongan emosional dan tidak mampu menghargai atau berempati terhadap orang lain.

Berdasarkan uraian diatas dapat dijelaskan bahwa dengan adanya kecerdasan emosional akan membantu remaja dalam mengendalikan sikap dan perilakunya agar sesuai dengan norma sosial. Pengendalian kecerdasan emosional yang baik dapat menurunkan tingkat konformitas dalam lingkungan sosial remaja. Oleh karena itu, apabila remaja memiliki kecerdasan emosional yang baik, maka tingkat konformitas akan rendah.

Kecerdasan emosinal yang baik ditunjukkan dengan adanya kepekaan dalam mengelola perasaan, kemudian menjadikan kerangka dalam berperilaku, bersosial atau mengambil keputusan yang tepat. Berkaitan dengan hubungan sosial, remaja harus menyesuaikan diri dengan orang di luar lingkungan keluarga, seperti, kelompok teman sebaya. Monks (Haditono, 2002) menyatakan pengaruh kelompok sebaya terjadi karena remaja lebih banyak berada di luar rumah bersama dengan teman-teman sebaya 
sebagai kelompok. Kelompok teman sebaya memiliki aturan tertentu yang harus dipatuhi oleh remaja sebagai anggota kelompoknya. Penyesuaian remaja terhadap norma dengan berperilaku sama dengan kelompok teman sebaya disebut konformitas.

\section{PENUTUP}

Kesimpulan yang dapat ditarik dari penelitian ini adalah sebagai berikut, ada hubungan yang signifikan antara kecerdasan emosional dan konformitas dengan koefesien korelasi $\left(r_{x y}\right)$ sebesar 0,682 dan $\mathrm{p}=0,000(<0,05)$. Artinya semakin tinggi kecerdasan emosional maka tingkat konformitas semakin rendah, dan sebaliknya kecerdasan emosionalnya rendah maka tingkat konformitasnya tinggi.

Hasil analisis menyatakan ada hubungan yang signifikan antara kecerdasan emosional dengan konformitas siswa kelas VIII SMP N 1 Kandangan Temanggung. Artinya semakin tinggi kecerdasan emosional maka tingkat konformitas semakin rendah, dan sebaliknya kecerdasan emosionalnya rendah maka tingkat konformitasnya tinggi.

Berdasarkan analisis deskriptif untuk skor kecerdasan emosional berada pada kategori rendah dengan presentase $32,1 \%$ dan untuk skor konformitas berada pada kategori tinggi dengan presentase 34,9\%. Guru BK dapat meningkatkan skor kecerdasan emosional dengan cara mengurangi skor konformitas siswa terlebih dahulu.

Bagi peneliti selanjutnya, disarankan agar bisa melakukan penelitian dengan judul yang berbeda, dengan cara merubah atau menambahkan variabel lain di dalam judul ini.

\section{DAFTAR PUSTAKA}

A.K.L, Mangun Nurmala. 2013. Hubungan Antara Kecerdasan Emosionaldengan Penyesuaian Sosial Siswa Kelas X SMK PGRI 02 Salatiga. Skripsi.

Ali, $\quad$ Mohamad. 1984. PenelitianKependidikan Prosedur dan Strategi. Bandung:Angkasa

Ali, Mohammad, Mohammad Asrori. 2004. Psikologi Remaja. Jakarta : PT BumiAksara

Anonim, 2000. Asch Soloman (1958), Soloman Asch Experiment (1958) A Studyof Conformity.

Arikunto, S. 2006. Prosedur Penelitian Suatu Pendekatan Praktek. Jakarta:PT Rineka Cipta.

Azwar, S. 2003. Penyusunan Skala Psikologi Cet12. Yogyakarta: PustakaPelalajar.

Azwar, S. 2009. Reliabbilitas dan Validitas. Yogyakarta: Pustaka Pelajar.

Cialdini, Reuven Bar-On. 2002, \& Goldstein, N. J. 2004. Social Influence: Compliance And Conformity. Annual Review of Psychology, 55, 591-621. 
George \& Mallery. 1995. SPPS/PC, Step by Step: A Simple Guide and Reference. Balmont: Wadsworth Publishing Companu.

Goleman, Daniel. 2000. Emotional Intelligence (terjemahan). Jakata : PT Gramedia Pustaka Utama.

Goleman, Daniel. 2000. Working With Emotional Intelligence (terjemahan). Jakarta: PT. Gramedia Pustaka Utama.

Latipun. 2002. Psikologi Eksperimen. Malang: UUM Press.

Lusi, Samuel S. 2014. SEIP Intelligence. Yogyakarta : PT. Kanisius.

M, Danni Ronnie. 2006. Menghadirkan prinsip-prinsip Kecerdasan Emosionaldan Adversitas dalam Kegiatan Belajar Mengajar. Jakarta Selatan: PT. Mizan Publika.

Monks, F. J. Knoers, A. M. P. Haditono, SR. 2002. Psikologi Perkembangan: Pengantar Dalam Berbagai Bagiannya. Yogyakarta; Gajah Mada University Press.
Myers, David G. 2012. Psikologi Sosial. Jakarta Selatan: Penerbit Salemba Humanika.

Rachmawati, Fema. 2013. Hubungan Kecerdasan Emosi Dengan Konformitas Pada Remaja di SMA Muhammadiyah 3 Yogyakarta. Universitas Negeri Yogyakarta. Skripsi.

Sarlito W. Sarwono, Eko A. Minarno. 2009. Psikologi Sosial. Jakarta: Salemba Humanika.

Sarwono, Sarlito W. 2009. Psikologi Sosial. Jakarta: Salemba Humanika.

Sears, D.D dan Peplau, L.A. 1999. Psikologis Sosial. Alih Bahasa: Michael, A.Jilid kedua. Jakarta: Erlangga.

Sugiyono. 2010. Metode Penelitian Kuantitatif Kualitatif \& RND. Bandung: Alfabeta.

Zebua, A \& Nurdjayadi, R.2001. Hubungan Antara Konformitas dan Konsep Diri Dengan Perilaku Konsumtif Pada Remaja Putri. Vol 3. Jakarta: Universitas Taruma Negara 